\title{
Chemical Distribution and Structure of Quaternary Metal Chelates in Aqueous Solution Involving Asparagine and Uracil
}

\author{
SURABHI SINHA $^{1^{*}}$, V. P. SHUKLA ${ }^{2}$, P. P. SINGH ${ }^{1}$ and V. KRISHNA ${ }^{3}$ \\ ${ }^{1}$ Department of Applied Sciences (Chemistry), United College of Engineering \& Research, \\ Allahabad, UP -211010, India \\ ${ }^{2}$ Department of Applied Sciences (Chemistry), \\ B. B. S. College of Engineering \& Technology Allahabad, UP, India \\ ${ }^{3}$ Department of Chemistry, University of Allahabad, Allahabad, UP -211002, India \\ rush2surabhi@yahoo.com
}

Received 10 October 2013 / Accepted 13 November 2013

\begin{abstract}
Ternary and quaternary metal chelates of some biologically important bivalent transition metal ions viz. $\mathrm{Co}(\mathrm{II}), \mathrm{Ni}(\mathrm{II}), \mathrm{Cu}(\mathrm{II})$ and $\mathrm{Zn}$ (II) formed with biologically significant ligands, viz. Asparagine (A) and Uracil (B) have been investigated. The relevant stability constants and complexation equilibria of quaternary metal chelates in solution at $30 \pm 1{ }^{\circ} \mathrm{C}$ and at constant ionic strength $\left(\mathrm{I}=0.1 \mathrm{M} \mathrm{NaNO}_{3}\right)$ have been studied potentiometrically. Equilibrium concentrations of all species in multimetal-multiligand system, concentration of each metal and complexing agent have been calculated. Species distribution curves are obtained by plotting percent (\%) concentration of the species obtained through SCOGS computer technique against $\mathrm{pH}$. The distribution curves are finally sketched by running the computer program ORIGIN 4.0. The metal ligand formation constant of MA, MB, MAB and M1M2AB type of complexes follow Irving William order. The order of stability constants of quaternary systems has been observed and solution structures of metal complexes with said ligands have been discussed.
\end{abstract}

Keywords: Potentiometrically, Quaternary systems, Stability constants, Chelates

\section{Introduction}

The metal chelates play an important role in various fields of biological ${ }^{1}$, analytical ${ }^{2}$, industrial $^{3}$ and medicinal ${ }^{4}$ importance. Biological system contains various essential and nonessential or potentially toxic metal ions ${ }^{5}$ sodium, calcium, manganese, cobalt, copper, zinc, lead, mercury and cadmium, etc. The human body contains many chelating agents ${ }^{6}$ such as amino acids, globins, proteins, enzymes, carboxylic acids and nucleic acid-bases, which form chelate compounds with sodium, magnesium, potassium, calcium, manganese, iron, cobalt, copper, zinc, molybdenum, etc. Complexation of metal ions of biological importance with amino acids, small peptides and their derivatives are of great significance, as many of 
these systems offer simple models of otherwise complex metal-amino acids equilibria occurring in enzymatic process ${ }^{7}$. Mixed-ligand, mixed-metal complexes involving more than one metal ions of the same or different types may prove as better models for multimetal-multiligand equilibrium occurring in the biological systems ${ }^{8,9}$. Such complexes are of importance in the study of bio-fluids particularly when hyperaccumulated metal ions are present for physiological or pathological nature ${ }^{10}$. Mutual influences between metal ions may be of antagonist or of synergistic nature ${ }^{11}$. Model studies with relatively simple molecules of known structure often yield valuable information that gives clues to the roles of metal ions in many enzymic reaction ${ }^{12,13}$. The present investigation, therefore, is an attempt to gather facts leading to a better understanding of the complexation pattern of metal chelates and multinuclear chelates towards some bivalent transition metal ions.

\section{Experimental}

For all, binary, ternary and quaternary systems following solution mixtures were prepared keeping the total volume $50 \mathrm{~mL}$ in each case.

Solution A: $5 \mathrm{~mL} \mathrm{NaNO}_{3}(1.0 \mathrm{M})+5 \mathrm{~mL} \mathrm{HNO}_{3}(0.02 \mathrm{M})+$ water

Solution B: $5 \mathrm{~mL} \mathrm{NaNO}_{3}(1.0 \mathrm{M})+5 \mathrm{~mL} \mathrm{HNO}_{3}(0.02 \mathrm{M})+5 \mathrm{~mL} \mathrm{~A}(0.01 \mathrm{M})+$ water

Solution C: $5 \mathrm{~mL} \mathrm{NaNO}_{3}(1.0 \mathrm{M})+5 \mathrm{~mL} \mathrm{HNO}_{3}(0.02 \mathrm{M})+5 \mathrm{~mL} \mathrm{~A}(0.01 \mathrm{M})+5 \mathrm{~mL}$ $\mathrm{M}_{1}(\mathrm{II})(0.01 \mathrm{M})+$ water

Solution D: $5 \mathrm{~mL} \mathrm{NaNO}_{3}(1.0 \mathrm{M})+5 \mathrm{~mL} \mathrm{HNO}_{3}(0.02 \mathrm{M})+5 \mathrm{~mL} \mathrm{~A}(0.01 \mathrm{M})+5 \mathrm{~mL}$ $\mathrm{M}_{1}(\mathrm{II})(0.01 \mathrm{M})+5 \mathrm{~mL} \mathrm{~B}(0.01 \mathrm{M})+$ water

Solution E : $5 \mathrm{~mL} \mathrm{NaNO}_{3}(1.0 \mathrm{M})+5 \mathrm{~mL} \mathrm{HNO}_{3}(0.02 \mathrm{M})+5 \mathrm{~mL} \mathrm{~A}(0.01 \mathrm{M})+5 \mathrm{~mL}$ $\mathrm{M}_{1}$ (II) $(0.01 \mathrm{M})+5 \mathrm{~mL} \mathrm{~B}(0.01 \mathrm{M})+5 \mathrm{~mL} \mathrm{M}_{2}(\mathrm{II})(0.01 \mathrm{M})+$ water

Where $\mathrm{M}_{1}$ (II) and $\mathrm{M}_{2}$ (II) are $\mathrm{Co} / \mathrm{Ni} / \mathrm{Cu}$ and $\mathrm{Zn}, \mathrm{A}=$ Asparagine and $\mathrm{B}=$ Uracil

Total volume in each case was raised up to $50 \mathrm{~mL}$ and ionic strength (I) of all solutions was maintained constant $\mathrm{I}=0.1 \mathrm{M}\left(\mathrm{NaNO}_{3}\right)$.

Each set of solution was then titrated against alkali $(\mathrm{NaOH})$. The $\mathrm{pH}$ meter reading with progressive addition of alkali to the titration mixtures were noted, when the reading of $\mathrm{pH}$ meter stabilized. The $\mathrm{pH}$ values were plotted against the volume of $\mathrm{NaOH}$ and the titration curves were obtained. The titrations were discontinued on the appearance of turbidity.

\section{Results and Discussion}

The protonated form of asparagine is titrated as a biprotic acid, due to successive deprotonation of the $-\mathrm{COOH}$ and the $\mathrm{NH}_{3}{ }^{+}$moieties respectively. Asparagine is a bidentate ligand coordinating through one amino group and one carboxylate $\mathrm{O}$ atom.<smiles>C[NH2+]C(CC(N)=O)C(=O)[O-]</smiles>

Figure 1. Solution structure of asparagine (Asp)

Uracil, a pyrimidine undergoes keto enol tautomeric shifts because of its resonance structure due $-\mathrm{NH}_{2}$ and $-\mathrm{OH}$ substrant. The keto tautomer referred as the lactam structure while the enol tautomer is referred as lactim structure. 


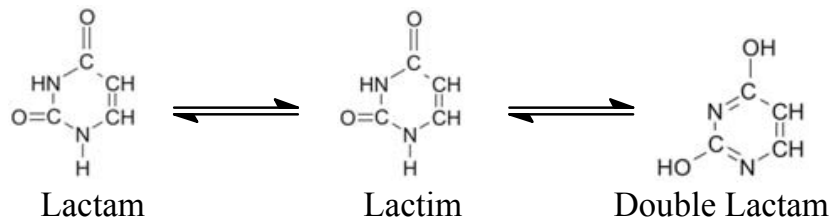

Figure 2. Keto enol tautomers of Uracil

Infra red and ultra violet spectral studies ${ }^{14-15}$ has shown that uracil exists in diketo structure. On the basis of UV measurements in aqueous solution, uracil exists primarily in the diketo form whereas in alkaline solution, it exists as approximately 1:1 mixture of the two possible deprotonated forms. Two overlapping absorption bands with $\lambda_{\max } 260$ and $284 \mathrm{~nm}$ have been reported for proton ionization from neutral uracil with a conclusion that protons ionize simultaneously from both $\mathrm{N}_{1} \mathrm{H}$ and $\mathrm{N}_{3} \mathrm{H}$ groups.

In $\mathrm{Ni}(\mathrm{II}), \mathrm{Co}(\mathrm{II})$ and $\mathrm{Zn}(\mathrm{II})$ complexes, uracil ${ }^{16}$ acts as a monodentate ligand coordinating through only one nitrogen, but in the $\mathrm{Cu}(\mathrm{II})$ complex, it is bidentate coordinating through carbonyl oxygen and nitrogen.

For evaluation of stability constants by the SCOGS computer program ${ }^{17}$ in a system of the two different metal ions $\mathrm{M}_{1}$ and $\mathrm{M}_{2}$ and two different ligands $\mathrm{A}$ and $\mathrm{B}$ in aqueous solution complex formation may be described according to equilibrium.

$$
\mathrm{pM}_{1}+\mathrm{qM}_{2}+\mathrm{rA}+\mathrm{sB}+\mathrm{t}(\mathrm{OH})=\left(\mathrm{M}_{1}\right) \mathrm{p}\left(\mathrm{M}_{2}\right) \mathrm{q}(\mathrm{A}) \mathrm{r}(\mathrm{B}) \mathrm{s}(\mathrm{OH}) \mathrm{t}
$$

The overall stability constant $\left(\beta_{\text {pqrst }}\right)$ defined may be used to calculate the species distribution curves that provides the clues for the formation equilibria of the complexes. Where the stiochiometeric numbers $\mathrm{p}, \mathrm{q}, \mathrm{r}, \mathrm{s}$ are either 0 or positive integers and $\mathrm{t}$ is a negative integer for a protonated species, positive for a hydroxo or a deprotonated species and zero for a neutral species.

$$
\beta_{\mathrm{pqrst}}=\frac{\left[\left(\mathrm{M}_{1}\right) \mathrm{p}\left(\mathrm{M}_{2}\right) \mathrm{q}(\mathrm{A}) \mathrm{r}(\mathrm{B}) \mathrm{s}(\mathrm{OH}) \mathrm{t}\right]}{\left[\mathrm{M}_{1}\right]^{\mathrm{p}}\left[\mathrm{M}_{2}\right]^{\mathrm{q}}[\mathrm{A}]^{\mathrm{r}}[\mathrm{B}]^{\mathrm{s}}[\mathrm{OH}]^{\mathrm{t}}}
$$

Quaternary system observe presence of Multinuclear complex species, protonated ligand species; $\mathrm{AH}_{2}, \mathrm{AH}, \mathrm{BH}$, binary and ternary complex species viz. [ $\left.\mathrm{M}_{1}(\mathrm{II})-\mathrm{A}-\mathrm{BH}\right]^{-}$and $\left[\mathrm{M}_{2}(\mathrm{II})-\mathrm{A}-\mathrm{BH}\right]^{-}$(Figure 3,4$)$.

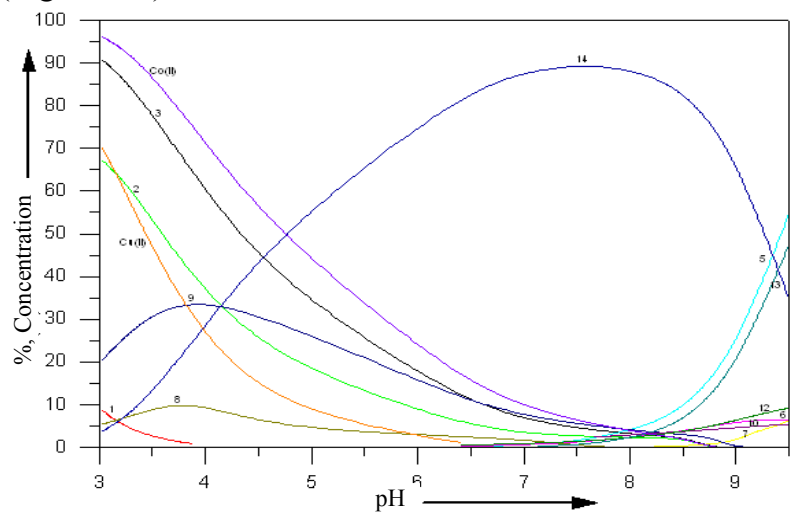

Figure 3. Distribution curves of 1:1:1:1 $\mathrm{Cu}(\mathrm{II})-\mathrm{Co}(\mathrm{II})$-asparagine-thymine system; (I) $\mathrm{AH}_{2}$ (2) $\mathrm{AH}(3) \mathrm{BH}(4) \mathrm{Cu}(\mathrm{OH})^{+}$(5) $\mathrm{Cu}(\mathrm{OH})_{2}(6) \mathrm{Co}(\mathrm{OH})^{+}$(7) $\mathrm{Co}(\mathrm{OH})_{2}$ (8) $\mathrm{CuA}$ (9) $\mathrm{CuB}$ (10) $\mathrm{CoA}$ (11) $\mathrm{CoB}$ (12) $\mathrm{CuAB}$ (13) $\mathrm{CoAB}$ (14) $\mathrm{CuCoAB}$ 


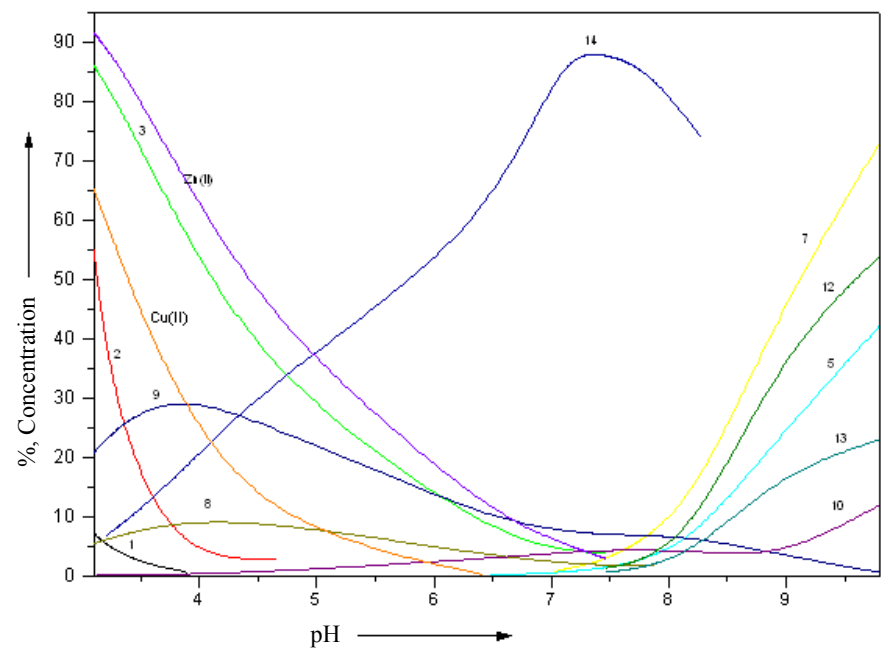

Figure 4. Distribution Curves of 1:1:1:1 Cu(II)-Zn(II)-Asparagine-Thymine system; (I) $\mathrm{AH}_{2}$ (2) $\mathrm{AH}(3) \mathrm{BH}(4) \mathrm{Cu}(\mathrm{OH})^{+}$(5) $\mathrm{Cu}(\mathrm{OH})_{2}(6) \mathrm{Zn}(\mathrm{OH})^{+}$(7) $\mathrm{Zn}(\mathrm{OH})_{2}$ (8) $\mathrm{CuA}$ (9) $\mathrm{CuB}$ (10) $\mathrm{ZnA}$ (11) $\mathrm{ZnB}$ (12) $\mathrm{CuAB}$ (13) ZnAB (14) $\mathrm{CuZnAB}$

The free metal ions and protonated ligand species of both the ligands have been found to follow a pattern of decreasing concentration with rise in $\mathrm{pH}$ indicating their involvement in complex formation. It is clearly evident from Speciation curves that in comparison to $\mathrm{MB}$ binary complexes, MA are present in appreciable amount which starts at higher $\mathrm{pH}$ region. The formation of binary complex may be assumed to follow the equilibrium:
$\left[\mathrm{AH}_{2}\right]$
$[\mathrm{BH}]^{-}$
$\begin{array}{cll}+ & \mathrm{M}_{1}{ }^{2+} & \rightleftharpoons \\ + & \mathrm{M}_{1}^{2+} & \rightleftharpoons \\ + & \mathrm{M}_{2}{ }^{2+} & \rightleftharpoons\end{array}$
$\left[\mathrm{M}_{1}(\mathrm{II})-\mathrm{A}\right]+2 \mathrm{H}^{+}$
$\left[\mathrm{M}_{1}(\mathrm{II})-\mathrm{BH}\right]+$
$\left[\mathrm{M}_{2}(\mathrm{II})-\mathrm{A}\right]+\mathrm{H}^{+}$

The concentration of binary complexes decreases probably due to formation of mixedligand complexes, which are found to be in appreciable concentration $(\sim 20-50 \%)$ in the $\mathrm{pH}$ range $\sim 3-4.5$ Declining concentration profiles of [M(II)-Uracil] and [M(II)-Asparagine] indicate the step wise formation of mixed ligand complexes in the $\mathrm{pH}$ range $\sim 7.0-9.3$. The complexation equilibria of ternary complexes have been derived on the basis of the speciation curves as follows:

$$
\begin{aligned}
& {[\mathrm{AH}]^{-}+\mathrm{M}_{1}^{2+}+[\mathrm{BH}]^{-} \rightleftharpoons\left[\mathrm{M}_{1}(\mathrm{II})-\mathrm{A}-\mathrm{BH}\right]^{-}+\mathrm{H}^{+}} \\
& {[\mathrm{AH}]^{-}+\mathrm{M}_{2}^{2+} \rightleftharpoons+[\mathrm{BH}]^{-}[\mathrm{Zn}(\mathrm{II})-\mathrm{A}-\mathrm{BH}]^{-}+\mathrm{H}^{+}}
\end{aligned}
$$

The alternative form of complexation equilibria may be assumed as:

$$
\begin{array}{lll}
{\left[\mathrm{M}_{1}(\mathrm{II})-\mathrm{A}\right]+[\mathrm{BH}]^{-}} & \rightleftharpoons & {\left[\mathrm{M}_{1}(\mathrm{II})-\mathrm{A}-\mathrm{BH}\right]^{-}} \\
\left.\mathrm{M}_{2}(\mathrm{II})-\mathrm{A}\right]+[\mathrm{BH}]^{-} & \rightleftharpoons & {\left[\mathrm{M}_{2}(\mathrm{II})-\mathrm{A}-\mathrm{BH}\right]^{-}}
\end{array}
$$

For multinuclear system, the species distribution curve indicates the formation of quaternary complex according to the following equilibrium:

$$
[\mathrm{AH}]^{-}+\mathrm{M}_{1}{ }^{2+}+[\mathrm{BH}]^{-}+\mathrm{M}_{2}{ }^{2+} \rightleftharpoons\left[\mathrm{M}_{1}(\mathrm{II})-\mathrm{M}_{2}(\mathrm{II}) \mathrm{A}-\mathrm{B}\right]+2 \mathrm{H}^{+}
$$

The another form of equilibria may be represented as:

$$
\left[\mathrm{M}_{1}(\mathrm{II})-\mathrm{A}-\mathrm{BH}\right]-+\mathrm{M}_{2}(\mathrm{II}) \rightleftharpoons\left[\mathrm{M} 1(\mathrm{II})-\mathrm{M}_{2}(\mathrm{II})-\mathrm{A}-\mathrm{B}\right]+\mathrm{H}^{+}
$$


Quaternary complexes are found to be the dominant species, its maximum abundance being greater than $90 \%$ in the $\mathrm{pH}$ range $\sim 6$ to 8 . At $\mathrm{pH}>8.0$, there is a decline in the concentration of quaternary complex which may also be attributed to the formation of hydroxo species as the buffer region corresponding to the complexation equilibria has been found to be overlapping with the hydrolytic equilibria Decline in concentration of multinuclear complex may be explained on the basis of formation of hydroxo species.

$$
\mathrm{M}^{2+}+2 \mathrm{H}_{2} \mathrm{O} \rightleftharpoons \mathrm{M}(\mathrm{II})(\mathrm{OH})_{2}+2 \mathrm{H}
$$

Refined values of binary and ternary constants are listed in Table 3,4 which are in good agreement with those in literature .The overall stability constants of mixed-metal-mixed -ligand [Asparagine-Uracil-M1-M2] systems (Table 5) have been found to follow the following order:

$$
\mathrm{Cu}-\mathrm{Ni}>\mathrm{Cu}-\mathrm{Zn}>\mathrm{Cu}-\mathrm{Co}>\mathrm{Ni}-\mathrm{Zn}>\mathrm{Ni}-\mathrm{Co}>\mathrm{Co}-\mathrm{Zn}
$$

Stability constant and other related constants of binary, ternary and quaternary complexes of asparagine (A) and uracil (B) with different metal ions in aqueous solution at $30 \pm 1^{0} \mathrm{C} \mathrm{I}=0.1 \mathrm{M} \mathrm{NaNO}_{3}$ are given in the Table $1 \& 2$.

Table 1. Proton ligand formation constant of asparagine (A) and uracile (B)

\begin{tabular}{ccccccc}
\hline Proton ligand constants, $\log \beta_{\text {oorst }}$ & $\mathrm{p}$ & $\mathrm{q}$ & $\mathrm{r}$ & $\mathrm{s}$ & $\mathrm{t}$ & $\log \beta$ \\
\hline $\mathrm{H}_{2} \mathrm{~A}$ & 0 & 0 & 1 & 0 & -2 & 10.86 \\
$\mathrm{AH}$ & 0 & 0 & 1 & 0 & -1 & 8.72 \\
$\mathrm{BH}$ & 0 & 0 & 0 & 1 & -1 & 9.94 \\
\hline
\end{tabular}

Table 2. Hydrolytic constant of $\mathrm{M}^{+2}$ aq. ions

\begin{tabular}{lccccccccc}
\hline $\begin{array}{c}\text { Hydrolytic constant of } \mathrm{M}+2 \\
\text { aq. Ions (Log } \beta \text { p0000t }\end{array}$ & $\mathrm{p}$ & $\mathrm{q}$ & $\mathrm{r}$ & $\mathrm{s}$ & $\mathrm{t}$ & $\mathrm{Co}$ & $\mathrm{Ni}$ & $\mathrm{Cu}$ & $\mathrm{Zn}$ \\
\hline $\mathrm{M}(\mathrm{OH})$ & 1 & 0 & 0 & 0 & 1 & -8.23 & -8.10 & -7.89 & -6.29 \\
$\mathrm{M}(\mathrm{OH})_{2}$ & 1 & 0 & 0 & 0 & 2 & -17.83 & 16.87 & -14.92 & 13.10 \\
\hline
\end{tabular}

Table 3. Metal-ligand constants ((log $\beta$ porst) binary system

\begin{tabular}{cccccccccc}
\hline Complex & $\mathrm{p}$ & $\mathrm{q}$ & $\mathrm{r}$ & $\mathrm{s}$ & $\mathrm{t}$ & $\mathrm{Co}$ & $\mathrm{Ni}$ & $\mathrm{Cu}$ & $\mathrm{Zn}$ \\
\hline MA & 1 & 0 & 1 & 0 & 0 & 4.00 & 4.30 & 8.32 & 6.77 \\
MB & 1 & 0 & 0 & 1 & 0 & 6.34 & 7.16 & 8.93 & 8.25 \\
\hline
\end{tabular}

Table 4. Metal -ligand constants ((log $\beta$ porst) ternary system

\begin{tabular}{llllllllll}
\hline Complex & $\mathrm{p}$ & $\mathrm{q}$ & $\mathrm{r}$ & $\mathrm{S}$ & $\mathrm{t}$ & $\mathrm{Co}$ & $\mathrm{Ni}$ & $\mathrm{Cu}$ & $\mathrm{Zn}$ \\
\hline MAB & 1 & 0 & 1 & 1 & 0 & 11.55 & 12.74 & 12.12 & 14.58 \\
\hline
\end{tabular}

Table 5. Metal -ligand constants ((log $\beta$ pqrst) quaternary system

\begin{tabular}{llllllll}
\hline Complex & $\mathrm{p}$ & $\mathrm{q}$ & $\mathrm{r}$ & $\mathrm{s}$ & $\mathrm{t}$ & $\mathrm{Cu}-\mathrm{Zn}$ & $\mathrm{Cu}-\mathrm{Co}$ \\
\hline $\mathrm{M}_{1} \mathrm{M}_{2} \mathrm{AB}$ & 1 & 1 & 1 & 1 & 0 & 20.90 & 20.60 \\
& & & & & & Ni-Co & $\mathrm{Zn}-\mathrm{Co}$ \\
& & & & & & 20.15 & 17.85 \\
\hline
\end{tabular}

In aqueous solutions $\mathrm{Cu}^{2+}(\mathrm{d} 9)$ is tetragonally coordinated by six water molecules. Two axial water molecules lie at longer distances from the copper and are more labile than the four other water molecules. The hydrated nickel ion presents regular octahedral configuration. Six equivalent sites of coordination are available unless a stronger ligand field provokes a tetragonal distortion and ultimately a square planar configuration. Hexacoordinated nickel is expected to form a greater number of isomeric complex species than copper, whose coordination geometry is usually dominated by the four "equatorial bonds". The configuration of 
zinc can easily move from tetrahedral geometry to octahedral geometry depending upon the nature of bound ligands. Consequently the possible mixed species are in greater number than with copper. Metals having higher $\log \beta$ value of metal-A complex will be the first to attach with ligand A,which further attaches to another ligand B to satisfy its coordination number. Coordination sites of ligands still left free will then are occupied by another metal ion (Figure $5 \& 6$ ).

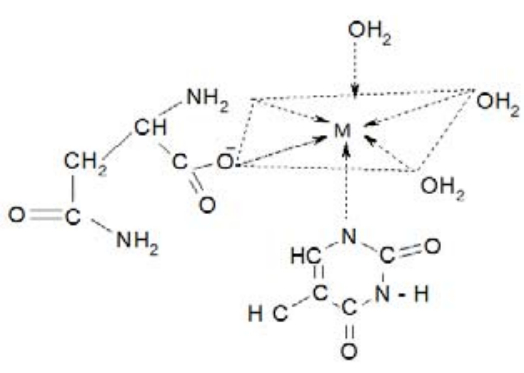

Figure 5. Proposed structure of ternary $\mathrm{Cu}(\mathrm{II})$-asparagine-uracil

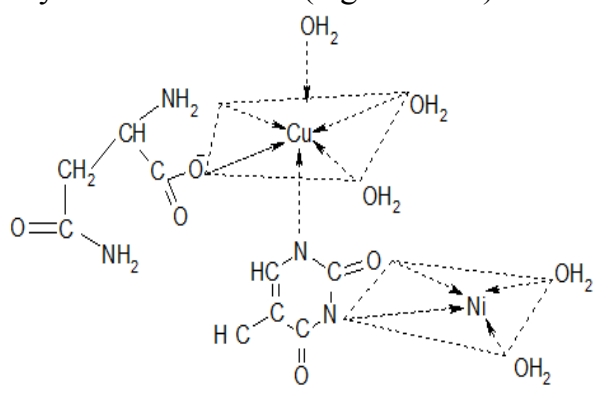

Figure 6. Proposed structure of quaternary $\mathrm{Cu}(\mathrm{II})-\mathrm{Ni}(\mathrm{II})$-asparagine-uracil

\section{References}

1. Sigel A and Sigel H, Metal Ions in Biological System, Marcel Dekker, New York, 1971- 2001, 1-38.

2. Yang X J and Pin C, Analyst, 2000, 3, 453-457; DOI:10.1039/A908278F

3. Jin J Y, Xu F and Miwa T, Electroanalysis, 2000, 12(8), 610-615; DOI:10.1002/(SICI)1521-4109(200005)12:8<610::AID-ELAN610>3.0.CO;2-K

4. Behari J R, Gupta S, Srivastava S and Srivastava R C, Ind Health, 1993, 31(1), 29-33.

5. Basinger M A, Jones M M, Holscher M A and Vaughn W K, J Toxicol Environ Health, 1988, 23(1), 77-89.

6. Frust, Chemistry of Chelation in Cancer, Spring Field Illinois, 1963.

7. De A K, Environmental Chemistry, New ACE International Publisher, $3^{\text {rd }}$ Ed., 1994, 81-83.

8. Williams D R, 'The metals of life' Van Nostrand Rienhold, London, 1971.

9. Garvan F L, 'Chelating Agents and Metal Chelates' (Ed., Dwyerb F P and Mellor D P) Academic Press, New York, 1964, 283-333.

10. Ed Zavier A V, 'Frontiers in Bioinorganic Chemistry', VCH, Verlagsgesellschaff, Weinhein, 1986.

11. Ed Eichhorn G L, Inorganic Biochemistry, Vol 1 and 2, Elsevier, Amsterdam, 1973.

12. Jasanada F, Urizzi P, Jean P S, Francis Le G, Gilles F and Françoise N, Bio Conjug Chem., 1996, 7(1), 72-81; DOI:10.1021/bc9500731

13. Sigel H, Metal Ions in Biological System, Mixed-Ligand Complexes, Ma Inc. New York 1973.

14. Zana R and Lang J, J Phys Chem., 1970 74, 2734-2736

15. Lang J, Strum J and Zana R, (a) J Phys Chem., 1973, 77, 2329-2335; (b) J Phys Chem., 1974, 78, 80; (c) Bioploymers, 1971, 10(12), 2639-2643; DOI:10.1002/bip.360101227

16. Sarkar A R, Ghosh P, Inorganica Chimica Acta,1983, 78, 39-41; DOI:10.1016/S00201693(00)86471-3

17. Sayce I G, Talanta, 1968, 15(12), 1397-1411; DOI:10.1016/0039-9140(68)80200-0 